CHARIES F. FERBERT

Mining Engineer

$321 \mathrm{C}$ Street

Anchorage, Alaska

September 4, 1962

$\underline{R E P O R T}$

NAME AND LOCATION OF MINE

Kathleen-Margaret (K-M) Copper proapect at Latitude 63-17 N., Longitude 146-35 W., west of the lower end of Maclaren Glacier in the Denali Mining District, Talkeetna Recording District, Alaska. The claims are in Section 2, 3, 10 and 11, T 195; R 6E, Falrbanks Meridian.

OWNERSHII

16 unpatented lode mining claims are owned by the Maclaren River Copper Corporation of Fairbanks, Alaska and are under lease and opt1on to Thomes E. Sllck. Title and existing agreements were not checked.

\title{
METALS
}

Copper and gold.

SUMARY

$5 \%$ copper ore with about $\$ 2.00$ in gold and silver has been developed in a portion of a quartz vein in limestone. Development by drifting, crosscutting, diamond drilling, percussion drililing and surfece trenchiag has disclosed an oreshoot about $71 / 2$ feet wide and 35 feet long with an lndicated development potential of about 25 tons per vertical foot over a known vertical distance of about 260 feet, a total of 6,500 tons.

It is doubtful if there are any other oreshoots with surface exposures within 3,000 feet from the original alscovery.

The northwesterly striking band of limestone, with some dolomite, may be $a$ "wlndow" In a thrust fault and a diorftic intrusion near the westerly property boundary may be emplaced withln the thruat plane. Northeasterly shearing, espectally at its intersection with easterly trending shear zones, may carry copper mineralization.

The geology would appear to be favorable for the existence of larger orebodies then have been digcovered but it appears than any that mey exist wll be found below a capping of greenstone or glacial dript.

\section{CONCUUSION AND RECOMEENDATION}

The known oreshoot is too small and too low grade to sustain a mining operation. While it is possible that this shoot represents leakage from a more important orebody, it is also possible that it is the root of an 
orebody now eroded or that it is almply a gmall chimney-like body at a favorable shear intersection. The risk is high and no development at depth $1 \mathrm{~s}$ recommended at this time.

However, the geological setting is latrigulag, the magnetometer gurvey Indicates that the presumabiy favorable limestone $1 \mathrm{~s}$ falrly extensive and is cut by northeasterly shearing, and some copper mineralization is rather widespread. These Pacts suggest that an electro-magnetic survey by campetent geophysiclsts might disclose a masalve sulfide orebody.

Although the high rigk lavolved in any development within an area that has yet to produce an operating mine mat be accentuated, it 18 felt that a moderate expenditure of about $\$ 5,000$ for an E-M survey is juatifled.

The known rock types within the ares studied are such that anomoliea caused by sulfides should be recognized without great difficulty and that orlliling of these anamolies might be undertaken with some rearonable arsurance of success. However, carbonaceour limeatone bas been found about flve miles weat of the $K-M$ and this could give misleading results if $1 t$ also occurs within the limestone beds at the K-M.

\section{EXAMINATION}

I arrived on the property, with a geological assistant, on Auguat 18 and departed on August 30. The weather was bad most of the time - It was elght days before there was a break long enough to make a solar observation for azimuth.

Underground and surface workings were tled to a co-ordinate system by trans1t-atadia, observable geolosy was mapped to the extent show on the attached maps and a magnetameter survey was run over part of the property.

Certain pertinent references, such as the assey resulta in the trenches and the geochemlcal survey by Leo Mark Anthony, were not available for study. References used were:

USGS bulletin 498 by Fred H. Moffit, 1912 GS C1rcular 332 by Chepman and Saunders, 1954

Alaska Copper Mines, Inc. I" to 201 map with sasay data, no date, copled by $\mathbb{E}$. Felrbanks in 1958

Maclaren River Copper Corporation $1^{\prime \prime}$ to $20^{\prime}$ map, not dated

Letter of February 14, 1958 Prom E. Falrbanks to F. S. Fettyjohn, with arsay data tied to above map.

\section{DESCRIPIION OF PROPERTY}

Location and Climate: The property $1 \mathrm{~s}$ located between the elevation of $\overline{3,100}$ feet and 4,500 feet along the weat side of the Maclaren Glacier and Maclaren River. This is above the tree line but the aurface is mantled with soll and glaclal debris. There are rock outcrops along cliff faces and in stream courses. 
Rainfall and onowfali are heavy, otorms are not infrequent and winters are sald to be severe. Normaliy, anow covers the ground from mid-september to the flrst part of June. However, underground or open-pit mining can be carried on duriag most, if not all, of the year.

Rock Types: The principel rock, classed and mapped as greenstone, consists of somewhat altered volcanica. Frequently, these are amygdalolial but dense varietles are not uncamon. Same members may be classed as olivine bssalt, otbers are less berlc. Epidote is comon and, near shears that have acted as solution channels, the rock may be altered to chloritic greenstone. very rarely, fine, native copper was found in the chloritic greenstone.

There 18 a band of Impure limestone that appears to lie under the greenstone, a position that may be due to thrust faulting. The limeatone varies in color from gray to dark green or nearly black. The green varlety is usually dolomitic. Like the greenstone, the linestone contains much epldote in bands that may be eltber parallel to or crosscut the bedating.

A hlghiy altered decite prophyry dike was noted both underground and on the surface. This is lnteresting since all of the copper showe seen by me on the West Fork of the Meclaren River are closely ssooclated with a simflar dike rock (which is ereah at those localities).

There is a diotitic intruaion near the western margin of the property. This rock (megascoplcally) appears to be composed of plagloclase, pyroxene and hornblende.

At the southerly margin of the diorite there is an exposure of a quartzose sediment that is tentatively classed as bornfels. It is thought that thls rock belongs in the upper part of the limeatone ser1es and, if so, may indicate a rather large body of limestone underneath glaclal debris to the south.

Mine Workings: At an elevation of 4,020 feet an adit has been driven northerly for some Ilve hunared feet; crosecuts bave been turned off and there 1s some driftiog on the ore structure. A blind ralse extends 100 feet up on a quartz veln.

At the polnt of discovery the vein has been pertially stripped and trenches have followed its course, or 1ts presumed course, for about 1200 feet.

Orebody: Drifting and drijling have disclosed an ore shoot about 35 leet long end 7 1/2 feet wide. The lowest 1ntersection by diamond driji is some 260 feet below the outcrop.

The orebody conslats of a quartz vein formed by replacement of limegtone and as a fissure fliling in greenstone. Where the wall rock is limestone the veln attalns wlaths of as much as 20 feet but it is rarely over a fow feet wide when the walls are greengtone. Selectlve replacement of limestone by quartz is often obvioue. 
The primary ore mineral is bornite whlch occurs as fracture fllling in the quartz and very alightly as replecement of elther limestone or greentione. Nuch of the quartz is barren.

Pyrite 1s rare but one small mass of solid pyrite in quartz is exposed at the orlginal discovery.

Improvements and gquipment: A good camp had been bullt in 1954 at an elevation of $3 \overline{100}$ feet. It la now in disrepair and there has been some theft. Usable buildinga are:

$13 \times 24$ inalated frame house with oll heater; needs roof repair

$13 \times 30$ Butler bullalag w1th ofl cook atove, tables, sink, storage, refrigerator, $h / w$ tank and heater, cook's quarter $\theta$, shower, wabling machine, tollet. Needs roop replacernent.

28x58 Butler bullding w1th $10 \times 10$ door. Needs repalr to atmactural members bent by snow logd.

$12 \times 16$ tent floor - no Prame

$13 \times 24$ floor of collapsed Prame builaing. Floor useble but no other part of bullaing id selvageable.

At the camp there are:

26 bundes 2'x50' Pibre-glase lasulation in rolls

Hobart 200 anp welder w/Chrysler Industrial englue. No leads. Kohler Model SM 21H $4 \mathrm{KW}$ gas-engine driven light plant. 7 ateel cota w/mattresses

7 steel folding chairs.

At the adit portal there 18 a freme building that needs repair of roof and siding. The whole structure, including the outdoor mine trackege is in iminent danger of collapse because the support la belng washed awry by a smeil creek. Witbin this building are:

Chicago-Pneumatic diamond drill w/20 - 10' rods; 13 - 5' rods;

4 - 3' roda' 1 - 10' AX owlvel type core barrel; several

AX and EX rigid type core barrela, incomplete.

Sullivan E-III alr tugger

Eimco $12 B$ rockershovel

GD 600 chin compressor w/Caterpillar englae and $5 \times 12$ recelver Stoper

Air driven electric generator

6" blower, electric

14" " "

$11 / 2$ electric transfer pump

Electric bit grinder (for carbide insert bits)

20 cf mine car

Irill steel and unused carbide Insert drill bits of varlous sizes. 
Underground there are:

Pump for dianond drill

Joy drill jumbo with two, shell nounted hesvy driters 20 ce mine car

Alr line, track, bose, etc.

No attempt bas been made to protect any of the equipment againgt rust but most of it appears to be usable.

The adit $1 \mathrm{~s}$ partially blocked by a mall rock fall but otherwho the workfings stand well.

\section{RESERVES}

Within a vertical diatance of 260 feet there are about 6500 tons of ore wlth an average of a little under $5 \%$ in copper and a little under $\$ 2.00$ per ton in gold and silver. Dilution in jiblag and milling los ses would alter the reserve f1gures to about 7,200 tons with a recoverable copper content of $4 \%$ and $\$ 1.60$ in gold and silver.

FOMENTIAL REGERVES

Persone familiar with the property have previously atated their bellef that oreshoots simllar to the one now developed would be found in an echelon occurrence along the quartz vein. I do not flnd sufficlent evidence to support that bellef and consider that ofmilar oreshoots are more likely to be conflued to the intersections of the more important easterly and northeasterly Practures. At least two additional 1ntersectlong may be inferred and are indlcated on the $1^{\mathrm{N}}$ to $40^{\prime}$ map. Drilling of these night be productive but there 1a scant asgurance that they would make substantial additions to reserves.

The K-M Is on the eastern end of a long "cogper belt" in which, as pointed out in Appendix A, the geology 18 eomewhet sintlar to that in which the well known and voluable kennecott orebodles were found. Insemuch as the great Jumbo orebody at Kennecott had an Insignlflcant surfece showlng (but the Bonanza was spectacular) there 18 some reason to hope that the $\mathrm{K}-\mathrm{M}$, or some other part of the "copper belt", contalne a large, rich orebody.

In my opinion the known geology does not warrant a drilling program but a search for a large conductor by electro-mangetic methods is juetifled. A carepul study of properly conducted $B-M$ work should indicate if there are potontial reserves on the property.

PROPOSED DEVELOPMEN

The magnet1c work (see Appendix B) appears to have some value in determining structure and should be contimued as it 1s relatively inexpensive and might make laterpretation of electro-magnetlc work more reliable.

It is proposed that in 1963 a well qualifled geophysical company be 1nstructed to conduct an electro-magnet1c survey along the preaumed strike of the Iimestone series from the mouth of Discovery Creek towards the 
diorite 1atrusive. The area of lnvestigation should be about 1500 feet w1de and 8000 feet long. Magnetameter work w1th a rapid reading and not necesearliy very accurate 1nstmment should also be conducted.

A study of the geophysical results durlag the wlyter of 1963-64 should de. termine $1 f$ there are any targets that are worth drililng and give some Idea of posalble a1ze. It will not pey to search out small conductors such as the developed oreshoot and only those that give some promise of large tonnage should be drilled.

If no strong conductors of apparent large slze are found, the project should be abandoned.

If suttable targets are discovered they should be arliled in 1964. Renovation of the camp and road repair would be required.

If the drflling indlcates the extatence of sufficlent ore of sufficlent grade the mine should be opened by an salt, possibly drive in imestone, from the 3200 foot elevation.

Although the inltial geophysical work will be moderate in cost, posalbiy a. Ilttle as $\$ 5,000$, the total expendtures for development prior to $\mathrm{mlll}$ construction would almost certalniy exceed $\$ 500,000$.

\section{MINING CONDTIIONS}

Except In the shear zones the ground stends well and requires little support.

An orebody thet 1s not more than 800 leet below the present adit level can be mined from an adit without pumplng problems.

\section{MIILING CONDITIONS}

The copper in the quartz veln and all of that seen as minor replacements of limestone or greenstone occurs in bornite with very few otbor sulfidea. There is a little gouge on some of the faults but talcy minerals are not cormor.

It would oeem that the ore is idealiy oulted to oimple, relatively inexpensive milling methods and that recovery should be high. Of course, the oxldized surface ores w1ll give same recovery problems. It is not expected that the oxddized zone w11l persist to any conslderable depth but there is no certain knowledge on that polnt.

Bornite is an 1deal mineral for concentration and there should be no difflculty in maintaining a concentrate grade of $40 \%$ copper.

\section{TRANSPORTATION}

The property is about 14 miles from the Denal1 Highway which provides alternate routes to a seaport, as bhown below: 
To Veldez:

If miles, Incomplete, sub-stendard/roed to Denell Rlghway. Regulres new bridge, all new culverts, campletion and same relocation - probable cost about $\$ 100,000$ to make all-weather rosd.

44 miles, falr gravel road, not normelly open in wlater. 185 miles, all-weather pavement, two lano.

No bulk loading facllities at Valdez, which 1a ratber infrequent port of call for steamers.

$243 \mathrm{mlleg}$, all truck, probable back-haul rate, $\$ 15$ to $\$ 20 /$ ton.

To Auchorege:

$14 \mathrm{milea}$, as above

90 mileg, falr gravel roan, not open in winter.

104 miles to Cantwell on railroed; no loading facilities.

215 mles, railroed to Anchorege docks, Clams and heavy lift equipment evallable. Port 1a scretimes closed by ice.

To Seward:

Same as to Anchorage, plus about 105 rallroad miles. Good port and fair facllities. Frequent port of call.

Since copper concentrates are a highly destrable back haul for ateemera, falrly reasonable rates can be negotlated. There 18 competing barge and steemer service to the smelter at Tacoma, Wabhington but the lowest frelght rate is to Japan where concentratea can be cerried as ballagt in vessels loaded with pulp or timber.

Japanese amelting charges are considerably less than those in effect at Tacoma.

POWER

If there is oufficient demand, water power can be developed on the East Fork of the Maclaren Rlver and on Boulder Creek. Power Ilnes would have to cross the bediy bratded Maclaren River.

For moderate power demanda diegel power could be provided at a cost of about $\$ 0.035$ per KWH.

Coal is avallable from the rallroed belt by trucking from Cantwell or, posilbly, by opening the caal beds near Delta Junction (Jarvis Creek). This would require a truck heul of about 135 miles.

TIMBER

There is no local timber and very little sultable timber along the Denall Highway. The best source would be in Prince William sound by way of Valdez. 
Page - 8 .

\section{WATER SUPYLY}

Spray Creek and Discovery Creek probebly can oupply enough water for a 500 ton per day operation even during the winter montbs.

\section{OPERATING COSTS}

There is no point in preparing a cost est1mate for the developed oresboot. Since it has taken over 800 feet of openings and well over 2000 feet of drililing to develop some 7000 tons of mill feed it is obvious that even if the discovery rate should be substantlally improved the development cost per ton of ore would come close to equally the net smelting returns after frelght, smelting and marketing charges.

However, it might be helpful to study the possible costs if there should be found oufficlent ore to malatale a 500 tpd operation for a period of 10 years, $1 . \theta ., 1,500,000$ tons. If we agsume that an orebody of that alze or orebodies aggregating that tonnage are found in 11 rm limestone and that development and stope preperetion costs w113 not exceed $\$ 2.00$ per ton of ore, the mine should be profitable if the average grede is $3 \%$ recoverable copper witb $\$ 1.15$ per ton recoverable gold and allver and if the average aeling price, adjusted to 1963 costs, $18 \$ 0.30$ per pound of copper.

It is further assumed that present ocean frelght rates and smolting charges In Japan will be malntalned.

The bornlte ore should produce a concentrate thet will assay $40 \%$ copper, which, after amelting 108s, wlll yidld 780 lbs of copper per ton of concentrate.

The value per ton of concentrate la estimated as follows:

Nominal value of 720 Iba. of copper (3) $\$ 0.30 / 1 b$

Le日s: Salea expense @ \$0.035/1b. $\$ 234.00$ Freight, handling, insurance, amelting $27 \cdot 30$ 35.00 $\frac{62 \cdot 30}{171 \cdot 70}$

Add: gold and silver payment, net 15.00

\section{Deduct $5 \%$ royalty (?)}

Net value of concentrate at mine

The eatimated cost per ton of ore would be:

$$
\begin{array}{cc}
\text { Drect labor, oupplies and power, per ton of ore } & 6.00 \\
\text { Amortization of preproduction and conatruction } & \\
\text { costs of } \$ 2,500,000 & 1.70 \\
\text { Minimum allowance for pre-tax proflt and adminls- } & \\
\text { trative costs, } 35 \% \text { or } \$ 2,500,000 \text { per yesr } & 5.80
\end{array}
$$


The ratio of the net yalue of the concentrates (which contain $39 \%$ paid-for copper) to the above cost per ton 1813 to 1 . Thet 18, 13 tons of ore must be minea and milied to provide $\$ 377.35$ to cover costs ado profit in one ton of concentrate. Since the concentrate contalns $39 \%$ salable copper the mill heads muat contaln $39 / 13$ or $3 \%$ recoverable copper plus $\$ 1.15$ recoversble gold and allver.

\section{CONCLUSION}

There is a geological bet that a sizeable orebody or group of orebodles may be found. If auch postulated orebodlea contain 3\% recoverable copper plus a little more than \$l.00 per ton in gold and allver, they should be profitable.

Geophysical exploration has been recommended and it should be noted that $3 \%$ copper would be close to the lower limit of detectablilty for a clean bornite ore in ilmestone.

Charles F. Herbert

Reglstered Mining Englneer 


\section{GEOLOGY}

Map A gives a general picture of the distribution of the principal rock types: largely greenstone whlch compriaes amydaloidal and dense lave flows; limestone and dolomite in a nortbwesterly trending band; diorite and bornfels (?).

The Ilmestone beds appear to underlie the greenstone but the presence of amydaloidal lavas wich can be formed only subaerialiy make it doubtful if the IImeatone ig intercalated With the greenstone. However, the base of the limestone has not been seen and it is posalble that the limestone preartes the greenstone and is separated from it by an exosional unconformity.

It is also possible that the IImestone is infolded Into the greenstone and that, localiy, both have been lavolved in overturn folotng. Considerable effort wa made to determine strikes and dips of the beds but only a few measurements are considered to be reliable. These indicate an anticlinal structure that is alfficult, but not impossible, to reconclie with overturning.

A somewhat afmilar problem Involving the greenstone and limestone was noted on the West Fork of the Maclaren River but, in that case, bedding was easily alscerned.

Tantatively I should guess that the greenstone has been carrled over the Iimestone by thrust faulting along an east-weat atrike with considerable readjustment of the thrust plates by b1gh angle faultiag aympathet1c to the "profound fault" postulated by Mofflt as occupylag the valley of the Maclaren River.

The diorite, which 1 a an outlier of Intruaions mapped by Moffit southwest of the property, may have been Intruded along a thrust plane.

The greenstone is belfeved to be Carboniferous in age and to be contemporaneous with the Nikolai greengtone of the Copper River valley. Similarly, the limeatone (If it is not pre-greenstone in age) is Triassic and probably contemporaneous with the ChItIstone limestane of the Copper River valley.

The oimilarity in rock types and ages and the presence of 10 temperature copper minerelization in the area under discusalon and the area near the famous Kennecott Mines has led to conjecture that Maclaren River deposits may equal those of Kennecott. Geological lnterpolation over the long distance separating the two areas is doubtiul at best, and there are dissimilarities.

At Kennecott the Chitistone IImestone lies confomebly on the Nikolal greenstone In spite of the difference in their respective ages. At the $K-M$ property the apperent position of the limestone is below greenstone, although 1t probably lles over another part of the greenstone serles. There $1 \mathrm{~s}$ a well defined zone in the Chitistone limestone which may be ore-bearing along cross-fold. At the $K-M$ no limestone zone favorable for replacement has been found; cross-folding may and probably does exist but it is complicated by much faulting. 
Sllght copper mineralization (1nverlably bornite is present; chalcopyrite is less comon) 1s found on almost all of the northerly or northeasterly striking shear or fracture zones where they intersect easterly shears. Th18 would 1ndicate a very w1despread source of copper and the olmple form of minerallzation over a conglderable vertical range would auggest stability of mlnerglizing condltions for a long time. It would seem thet replacement should take place tf the solutions should have had sccesa to any bede favorable for replacement by the type of golutions avaliable and at the temperatures then prevailing.

Host frequently copper replacement bodtes are formed in the more dolamitic beds of a Ilmestone serles. At Kennecott the ores were strictly conpined to dolomite and at Kennecott's new property near Kobuk, Alaska the ore 1a again exclusively confined to dolamite (a primary dolamite breccia).

Dolomite is quite cominon at the K-M. The lower portion of the exposure west of the portal is a green dolamite end dolamite, with some copper, 18 exposed fust north of the mouth of Dlscovery Creek. 
MAGNETOAETER SURVEY

A prelfminary magnetometer ourvey wa undortaken to see if such a survey would have value in determining structure where ourface exposures are poor or non-exigtent. There was no thought that a magnetometer would give any direct Indication of ore bince there is no megnetite or pyrrhotite assoclated with copper mineralization at the $K-M$.

It was expected that the greenstone beds would have discernibly different magnetic susceptiblittles and that the limestone would give a different response than the greenatone. It also seemed posalble that hydrotbermal alteration of the greenstone might have formed some magnetite from the malfic minerals and so form a gulde to solution channelways. It appears that both expectations were correct.

The instrument used was an Arvella "pocket magenetometer" which is fast and almple but la rather insensitive. Readinge are taken to 100 germes and at least two readinge were taken at each station. If the readings checked within 100 gammas they were recorded, otherwlae additional readings were made. The 1nstrument 1s affected by moloture and gives erratic bigho during rain. Since the weather was bad during the examlation over belf of the survey wes repeated.

Calibration had been made agaznat a Sharpe A-3, which 18 not a part1cularly sensitive ingtmment, so the absolute valuea recorded may be off by more than 1000 genmes, However, the relative values shown on the map are belleved to be accurate within 300 ganmas. No monitoring was done but stations were checked on separate days.

Stations were set 50 feet epart on E-W IInes and 100 feet apart on N-S lines.

The northwe readings before it was determined by 11eld measurement. In fact, a persiatent joint system had been misinterpreted as bedding and it was some time before a contact between an anydaloidal bed and a pine grained bed were traced out to corroborate the magnettc findings.

The know Ilmestone areas gave a low response, whlch suggest that the low from $400 \mathrm{ft}$. to $500 \mathrm{ft}$. east of the portal may Indicate limestone beneath a thin cover of greenstone. Since there 18 also a steep magnetic gradient about 350 ft. east from the portal and fractured greenstone and some bornite are exposed, the postulated imestone in this area may be orembearing.

other deductions may be made from the magnetlc map but it is not palt that any of the results should be interpreted as indicators of ore. They are useful orly in asglating in the study of proposed electromegnetic work. 
In addition to the magnetic survey shown on the map a traverse was carried irom the comp site up Discovery Creek. The resulta are 1nterpreted a Indicating thick greenstone for the flrst 1,500 feet from the camp (1.e. roughly parallel to the Maclaren River); then 900 feet in which limestone may underlie the exposed gxeenstone; then westerly up the creet for 1,000 feet in which somewhat erratic readings may show either varying depths of greenstone or feulting; then 200 feet of hydrothermally aitered greengtone followed by 600 feet of greenstone and, flnally, 500 feet of greenstone overlylug limeatone. The end point of the traverse wag about 700 feet ESE from the portal. 